Vol. 2, No. 1, 2021

Roman Kachmar

Lviv Polytechnic National University

12, Bandery Str., Lviv, 79000, Ukraine

(C) Kachmar R., 2021

https://doi.org/ 10.23939/tt2021.01.075

\title{
FEATURES OF OPERATION OF THE TESLA MODEL S90D ELECTRIC CAR IN THE CONDITIONS OF THE CITIES OF UKRAINE
}

\begin{abstract}
Summary. Tendencies of sustainable development of transport, the use of alternative energy sources, and requirements to the reduction of the carbon footprint on all stages of life cycle on all levels of road transport have led to the increase of the share of the electric car both at the first registration and used vehicles. The appearance of a large amount of used modern electric cars on the market caused the necessity to develop the procedures of provision their technical operation both by requirements of rational use and provision of traffic safety. Research of the use of electric car Tesla Model S90D in conditions of Ukraine is carried out with certain indicators of environment and with different settings of car parameters. This provides an opportunity to understand how much the given model of the electric car is appropriate in exploitation in different conditions and also to determine which parameters of electric car settings fit the economic usage in different conditions and different seasons most of all. By results of road research on the change of accumulator battery capacity depending on the temperature of the environment, we established that the capacity reduces by $1 \%$ with every degree of negative temperature. A comfortable range of temperatures is determined for the use of accumulator battery of car (from 0 to $20^{\circ} \mathrm{C}$ ) is determined. By results of the research, the indicators of the effectiveness of the use of electric car battery power saving mode are determined - the reduction of the consumption is from 14 to $29 \%$ depending on energy consumers. The significant impact of the pressure values in electric car tires on the energy consumption is established independently from turning on the energy consumers - the increase is from $10 \%$ to $40 \%$ depending on its speed of movement. Additionally, the determination of the indicators of electric car energy effectiveness for the speed of 140-150 km/h is carried out by which the energy use is 550-670 W h/km and provides the driving distance on the level of $160 \mathrm{~km}$.
\end{abstract}

Key words: electric car, exploitation, maintenance, failures, defects, energy consumption, accumulator battery, recuperation.

\section{INTRODUCTION}

Nowadays, a large number of leading European countries whether limit the usage with classic internal combustion engines (especially diesels) or totally refuse from the usage of such cars in favor of ecological transport operation - electric car [1-3]. However, some emphasize that the growth of energy consumption will cause new problems [4]. On the legislative level, in most countries citizens are encouraged in different ways to buy electric cars by giving them whether the opportunity to enter the central districts of the city or movement on the allocated lanes for public transport, or reduction of canceling the duty, free parkings, partial compensation of the car cost, intensive development of infrastructure, etc. [5,6]. Ukraine also cancelled import duty and VAT on electric cars, which caused the increase of the number of electric cars import to the country, especially used [7]. But, in Ukraine, electric cars are not for sale yet officially, which caused the absence of warranty service and the demand on the qualitative electric car service $[8,9]$. At the same time, the growth of release of different types and models 
of electric cars and their growth on the public roads requires the development of the method of exploitation and technical service of these electric cars. Proper exploitation and service of electric cars is the guaranty not only economically profitable and seamless usage of these cars. This is also a key factor relative to the safety of the driver and passengers as impropriate behavior with elements of delivery and different elements of electronics which are in the car can cause bad consequences and in some cases even to the electric car inflammation. That is why today it is important to determine the main rules of the effective exploitation of electric transport, in particular in our region, taking into account both climate conditions and existing energy consumers in electric cars. An important factor here is the operation of comfort systems, in particular, for instance, system of car interior heating because in internal combustion engines heat is received in result of their operation.

\section{RESEARCH STATEMENT}

By results of the change of European and Ukrainian market of the new and used vehicles, the growth of the number of electric cars in composition of car park and forecasts of demand on such vehicles, the problem of availability of services and specialists of appropriate level for providing services of electric cars technic exploitation is topical nowadays. Low motorization level in our country comparatively with allEuropean data testifies about a large potential and request of population for buying vehicles. Last year, in Ukraine more than 7100 electric cars are put on the registration, among them more than $90 \%$ are used [10]. By forecasts of the development of the market taking into account the tendencies of the development of automotive industry, implementation of new standards of certification and testing of cars, up to 2030 year more than $30 \%$ of car sales will make a segment of cars in Ukraine [11, 12], and in the world and European countries will make more [4]. Taking into account legislative initiatives, the perspectives of legal regulation of used cars market it is forecasted the further growth of the share of used cars including electric cars which will lead to saturation of the market by used transport with existing problems of cars with mileage and in case of electric cars with accumulator battery of lowered capacity.

Electric cars' speed and run are limited. They can run without recharging, depending on the class, on average 160-230 km [11, 13]. It also depends on the model, but the limit is always present. Modern accumulators do not allow yet to increase this indicator noticeably and not to overweight the car.

Full charging of accumulators can take to $8-10$ hours if not to use fast charging [14]. It should be taken into account during the time and travel planning.

That is why the task was set to research the change of electric car energy consumption depending on operational movement conditions to determine the rules and recommendations about effective electric car exploitation.

A large number of studies were carried out by the researchers in the field of sustainable development of transport, particularly the development of private electric transport. An interesting is a research carried out in [15], in which the cost of owning the different vehicles considering their wear during the exploitation period of 7 years is determined. It was shown that owning an expensive electric car does not always economically justified because of the significant cheapening of the last. However, as given in [16], in conditions of the use of determination of equivalent fuel consumption, the use of electric cars is to 10 times more economical than the use of cars with internal combustion engines on the territory of Ukraine, but worldwide trends are somewhat different [17].

A lot of researchers concentrate on the provision of energetic safety of our country more than on ecological or economic advantages from electric transport exploitation [13]. There are many theoretical kinds of research on the opportunity of electric car development [18], also, design developments are carried out and the search of ways of small series production organization of electric cars in Ukraine is ongoing, in particular, commercial light transport [11].

Concerning the determination of the effectiveness of electric car parameters, then many researchers carry out calculations, but concentrate whether on the data from the manufacturer or the imperfection of electric car systems, for example, neglect of motion parameters by the system of determination of the 
residual range of motion parameters [19]. However, none of these researchers carry out the analysis of the impact of different exploitation conditions and working energy consumers on the energy consumption by the car, and, as a consequence, on the run.

Although the electric car is simpler at the expense of its construction, at the same time, typical malfunctions are present, particularly in the car Tesla, there are not so many of them and they can be grouped by several groups $[8,18,19]$ :

- electricity, electronics, electric car mistakes (many unexpected mistakes, usually reset MCU, АКБ 12 В; key; display; graphic processor Tegra; charging port; battery power contacts; door handles; sensors of rain, parking, air suspensions);

- chassis of an electric car (rare gearbox, front constant velocity joints, silent blocks of suspension levers).

Instead of taking of usual maintenance every 10 or even 20 thousand kilometers, the modern electric car requires only annual maintenance with the aim of changing the cabin filter, checkup of the condition of windshield wipers and spacing blocks, general diagnostics of the electronic control unit. Usually, for the electric car, more time-consuming maintenance should be carried out, directed on the change of antifreeze, which is used for cooling the accumulator battery, changing the brake fluid, changing the brake pad, and controlling the oil in the gear system if necessary. The absence of an internal combustion engine and simplifying the maintenance and its cost allows forgetting about the change of oil and oil filter, air filter contamination, scheduled replacement of spark plugs, application of strangling, changing the cambelts or cam chains, turbines, neutralizer, setting of gas distribution phases, etc.

\section{RESEARCH METHODOLOGY}

To research the impact of different exploitation conditions on the amount of energy consumption, the electric car Tesla Model S90D (Fig. 1) was used, which is an all-wheel-drive sedan with two electric motors with a capacity of 422 h.p. Car is equipped with an accumulator battery with capacity $90 \mathrm{~kW} \cdot \mathrm{h}$, which allows driving to $550 \mathrm{~km}$ on one accumulator charge.

The general car run from the beginning of exploitation was $87355 \mathrm{~km}$, the car passed unscheduled maintenance previously before the research, and diagnostics of the battery in case of failure of some of its sections were additionally carried out. Control for the pressure values in tires and bringing them to nominal was carried out with the help of a verified manometer.

The research was carried out on the straight road segment with the length of $4 \mathrm{~km}$ at the environmental temperature range from 0 to $18{ }^{\circ} \mathrm{C}$ on the section of road Khmelnytskyi-Vinnytsia (Fig. 2), namely $2 \mathrm{~km}$ from the village Perogivtsi and $21 \mathrm{~km}$ from the city Khmelnytskyi.

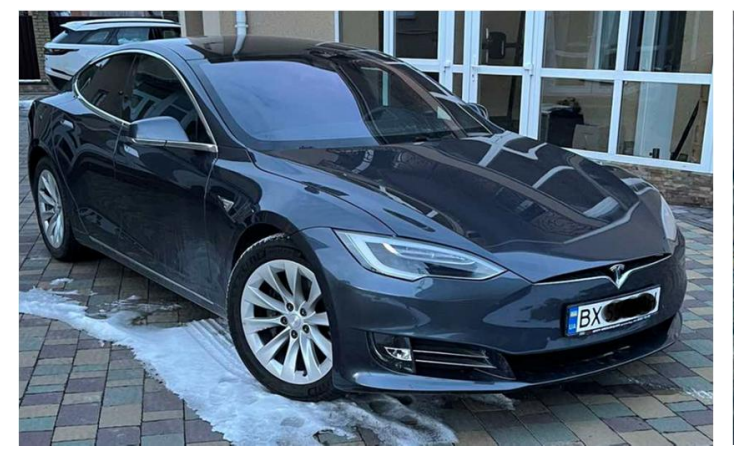

Fig. 1. General view of investigated electric car Tesla Model S90D

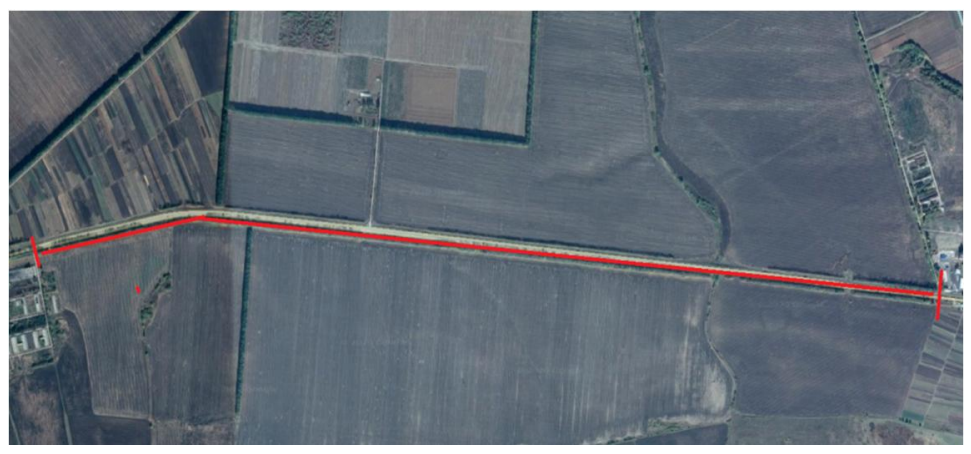

Fig. 2. Road segment for road tests conduction

There is a lot of factors from which the maximal run of an electric car without charging depends, as even incorrectly adjusted pressure in tires can significantly lower the run on one charge. Of course, one of the main factors is environmental temperature as even modern electric cars are not adapted to the 
qualitative exploitation in conditions of low temperatures, thus almost all they have liquid heating of accumulator batteries. Anyway, at low environmental temperature, electric car temperature strongly cools, its maximal capacity reduces, which, in its turn, causes the reduction of the maximal run. Additionally, at low temperature in the car cabin heating works constantly, and in parallel accumulator heating works that summarily can consume to $15 \mathrm{~kW} \cdot \mathrm{h}$ per every $100 \mathrm{~km}$ of run.

That is why, based on the analysis of available sources, forums, and own observations of exploitation indicators of the car, a plan is made for research to determine the electric car energy consumption on different car speeds depending from turned on the regime of energy recuperation and conditioner, turned on consumers - cabin heating and seats heating. Also, the determinative impact has set tire pressure, moreover, on the different forums the pressure $0.23 \mathrm{MPa}$ is intensively recommended to set for improvement of comfort and smooth movement, thus the manufacturer recommends setting the pressure at the level 3.0 $\mathrm{MPa}$. That is why research for given pressures in tires is also carried out.

Before the start of the research, depending on chosen regimes, it is needed to set the recuperation in standard regime in car parameters that allow using energy recuperation in different exploitation regimes maximally effectively. Setting the parameters of recuperation of investigated electric car Tesla Model S90D is given in Fig. 3.

We can see energy consumption on an on-board computer considering accumulator capacity and energy consumption per $1 \mathrm{~km}$ of road (Fig. 4), also we can calculate the forecasted run of the electric car on one charge at different car parameters.

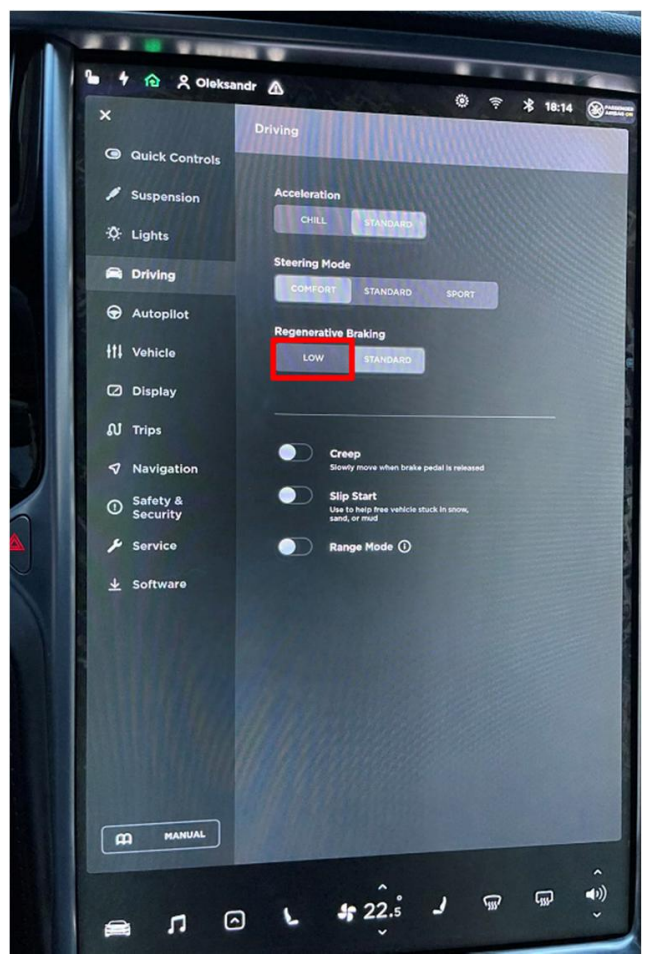

Fig. 3. Turning off the recuperation of investigated electric car Tesla Model S90D

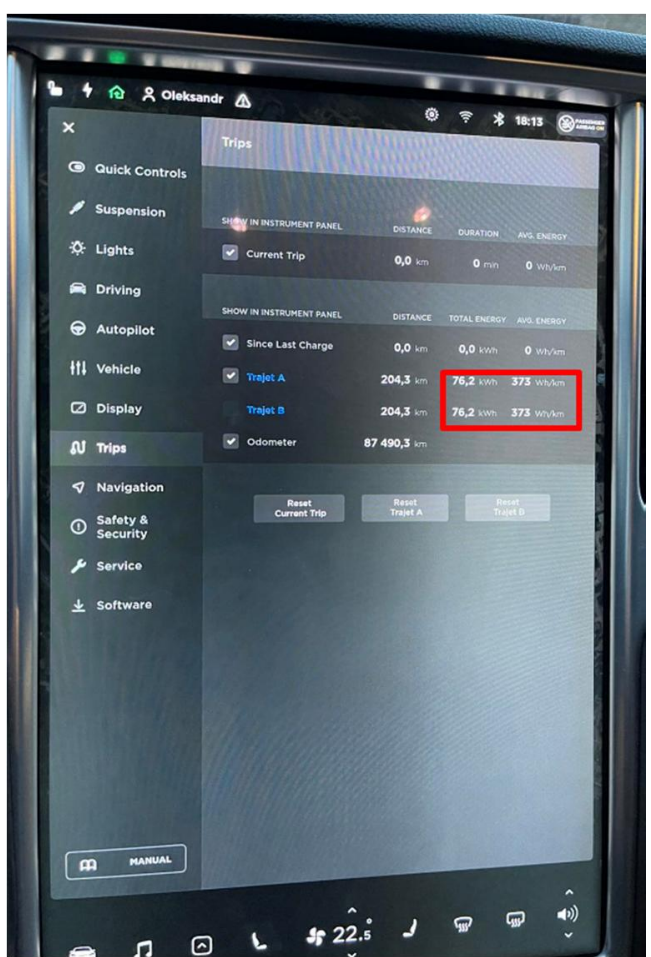

Fig. 4. Energy consumption of investigated electric car Tesla Model S90D

\section{ANALYSIS OF THE RESULTS OBTAINED FOR THE OPERATION OF TESLA ELECTRIC VEHICLES}

Results of carried out research of investigated electric car Tesla Model S90D for two values of speed, different combinations of turning on the consumers and accumulator energy-saving regimes are given in the Table 1. Additionally, testing at lowered pressure value in electric car tires and different combinations of turning on the consumers is carried out. 
The main indicators of testing the investigated electric car

\begin{tabular}{|c|c|c|c|c|c|c|c|c|c|c|c|c|c|c|c|c|}
\hline Indicator & 1 & 2 & 3 & 4 & 5 & 6 & 7 & 8 & 9 & 10 & 11 & 12 & 13 & 14 & 15 & 16 \\
\hline Car speed, $\mathrm{km} / \mathrm{h}$ & & & & & & & & & \multicolumn{8}{|c|}{95} \\
\hline Recuperation & + & - & + & - & $\mathrm{E}$ & $\mathrm{E}$ & + & + & + & - & + & - & $\mathrm{E}$ & $\mathrm{E}$ & + & + \\
\hline Conditioner & - & - & + & + & + & - & + & - & - & - & + & + & + & - & + & - \\
\hline Cabin heating & - & - & + & + & + & - & + & - & - & - & + & + & + & - & + & - \\
\hline Seat heating & - & - & + & + & + & - & + & - & - & - & + & + & + & - & + & - \\
\hline Tire pressure, Bar & 3 & 3 & 3 & 3 & 3 & 3 & 2,3 & 2,3 & 3 & 3 & 3 & 3 & 3 & 3 & 2,3 & 2,3 \\
\hline $\begin{array}{l}\text { Energy } \\
\text { consumption, } \\
\mathrm{W} \cdot \mathrm{h} / \mathrm{km} \\
\end{array}$ & $\underline{\infty}$ & $\stackrel{ \pm}{\Xi}$ & $\stackrel{\sim}{\sim}$ & $\stackrel{\infty}{\infty}$ & 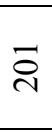 & $\stackrel{9}{2}$ & $\sqrt[n]{n}$ & సి & $\tilde{n}$ & $\stackrel{\circ}{\infty}$ & $\bar{\sim}$ & $\stackrel{\circ}{n}$ & 今్ & $\stackrel{+}{\sim}$ & 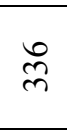 & 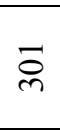 \\
\hline $\begin{array}{l}\text { Consumed energy, } \\
\mathrm{kWh} \text {. }\end{array}$ & $\frac{0}{\pi}$ & $\frac{\hat{n}}{0}$ & $\hat{\sigma}$ & $\stackrel{\Xi}{\Xi}$ & $\stackrel{\infty}{0}$ & $\begin{array}{l}\infty \\
\infty \\
0 \\
0\end{array}$ & $\underset{0}{0}$ & $\infty$ & $\underset{-}{0}$ & $\Xi$ & $\stackrel{\infty}{\sim}$ & $\stackrel{\Im}{\leftrightarrows}$ & 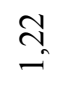 & $\hat{\sigma}$ & $\stackrel{\infty}{\sim}$ & $\stackrel{\sim}{=}$ \\
\hline
\end{tabular}

By results of conducted testing of investigated electric car Tesla Model S90D on different fixed values of speed and different combinations of turning on and accumulator energy-saving regimes, the diagram of the change of electric car Tesla Model S90D at different speed depending on consumers' combination is built (Fig. 5).

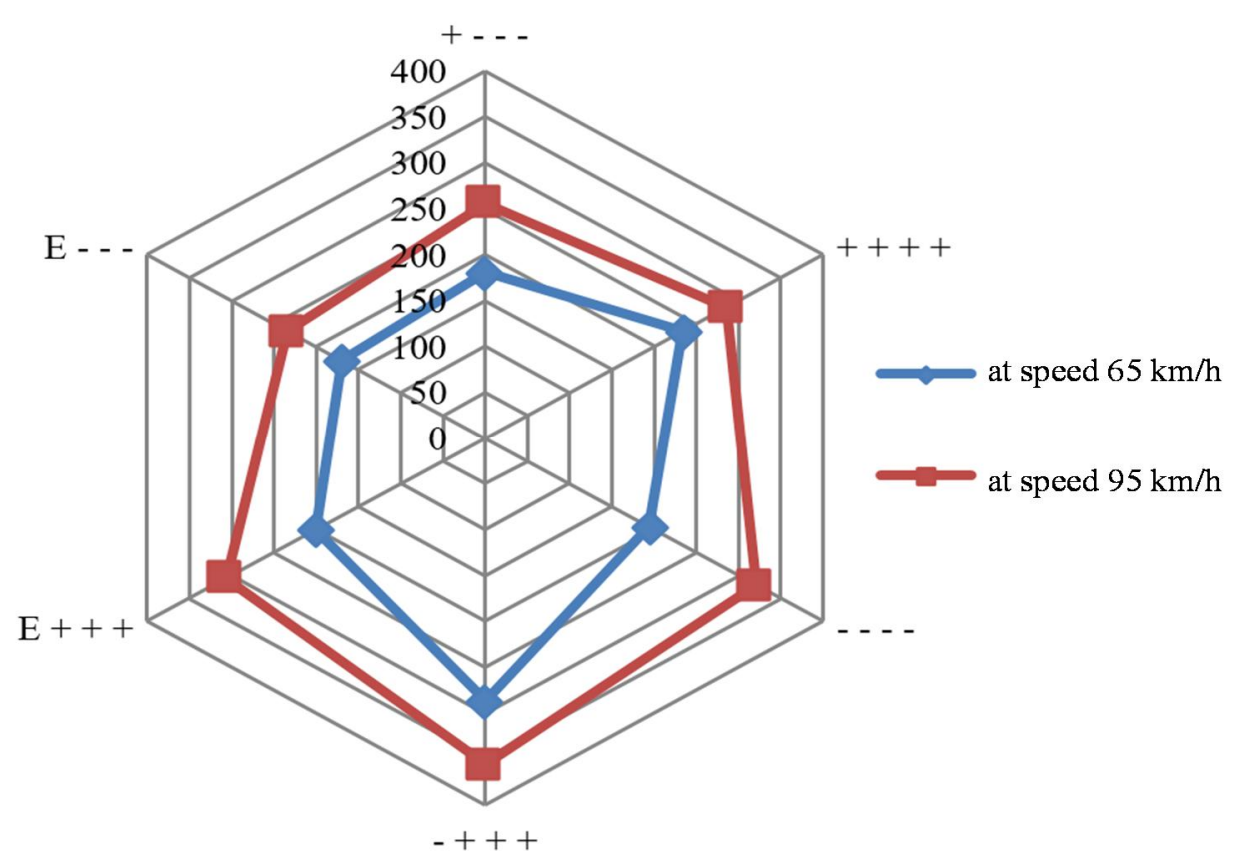

Fig. 5. Change of electric car Tesla Model S90D energy consumption $(\mathrm{W} \cdot \mathrm{h} / \mathrm{km})$ depending on consumers `combination and speed of movement

By results of conducted testing, it was obtained that at the same exploitation conditions two powerful energy consumers - cabin heating and seat heating - spend about $5 \mathrm{~kW} \cdot \mathrm{h}$ per $100 \mathrm{~km}$ of run.

Besides, the change of electric car Tesla Model S90D energy consumption is given separately depending on the speed of movement at different tire pressure values and turning on the consumers (Fig. 6). 


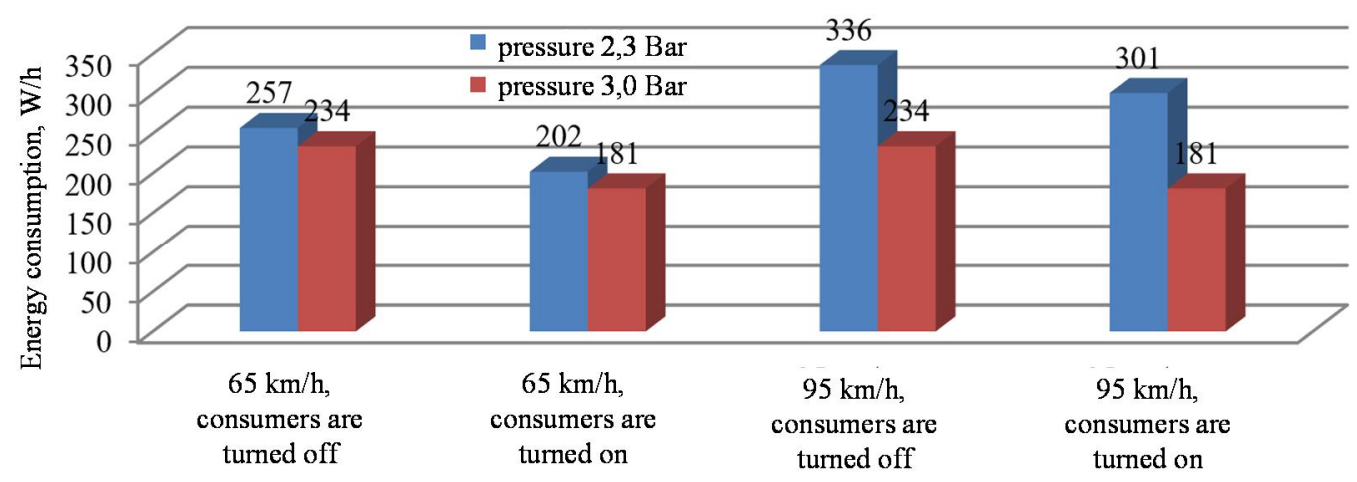

Fig. 6. Change of electric car Tesla Model S90D energy consumption depending on the speed of movement, tire pressure, and at turning on consumers

Based on carried out testing, the model of depending the electric car energy consumption from the impact of different factors is created due to obtained results. Indicators of the model of energy consumption are determined depending on turned on energy recuperation $\left(\mathrm{x}_{1}\right)$, turned on energy consumers, i.e. conditioner, heating or cabin heating $\left(\mathrm{x}_{2}\right)$, and tire pressure $\left(\mathrm{x}_{3}\right)($ Table 1):

$$
Q=232.875-14.375 x_{1}+35.875 x_{2}-9.125 x_{3}-8.875 x_{1} x_{2}-1.875 x_{1} x_{3}+45.625 x_{2} x_{3} .
$$

The obtained model indicates the direct impact of turned on energies recuperation, turned on energy consumers, i.e. conditioner, heating or cabin heating and tire pressure on electric car energy consumption,

Residual run on one charge depends significantly on the general number of energy consumers. That is why it will be practical to use the opportunity to heating-up (or cooling) of electric car cabin before running from the parking lot or the box to bring the cabin temperature to the comfortable while charging the electric car from the network.

An important factor of the increase of car run on the charge is electric car exploitation conditions. Specifically, in the condition of cities, the electric car instantly uses the recuperation for braking which provides an opportunity to accumulate the energy and increase maximal run without charging. By results of the conducted research, we established that the usage of the energy-saving regime of electric car battery allows reducing the energy-saving at the speed $65 \mathrm{~km} / \mathrm{h}$ and with turned on energy consumers by $29 \%$ and with turned off energy consumers - by $14 \%$. Besides, researching the speed $95 \mathrm{~km} / \mathrm{h}$ and with turned on energy consumers showed the reduction by $16 \%$, and with turned off energy consumers - by $22 \%$ at the same speed.

One more but not less important indicator of energy spending is the speed with which the car is moving. For instance, the electric car Tesla Model S90D on high speeds in the range of 160-200 km/h will have enough charge for $100-130 \mathrm{~km}$ of the run at the environmental temperature $0{ }^{\circ} \mathrm{C}$, which is almost four times less than claimed run by the manufacturer. And this is even though electric engine cools by the liquid cooling system which has a common contour with the cooling system of accumulator battery and is actuated by two electric pumps which are installed on the big and small cooling contours, i.e. there is a battery heating.

It is established that electric car accumulator battery significantly reduces its capacity at negative temperatures; the capacity reduces by $1 \%$ per every degree of frost - i.e. at $-10{ }^{\circ} \mathrm{C}$ the capacity of electric car accumulator battery and distance traveled will reduce by $10 \%$, which causes the increase of charging frequency in winter. The comfortable temperature for the usage of electric car accumulator battery is set in the range from 0 to $20^{\circ} \mathrm{C}$, moreover, the temperature growth also causes the reduction of the capacity because of intensive battery cooling - system protects it from overheating.

We obtained that at the car speed in the range $140-150 \mathrm{~km} / \mathrm{h}$ its drive range on one battery charge is about $163 \mathrm{~km}$, the car is not quite adapted to far travels on fast highways. Energy consumption on given speed is $550-670 \mathrm{~W} \mathrm{~h} / \mathrm{km}$, which is more than two times exceeds the consumption at the speed of $65 \mathrm{~km} / \mathrm{h} /$ 


\section{CONCLUSIONS}

1. Analysis of obtained results and calculation of obtained indicators after the testing carried out on the straight road segment at the same indicators of environment and different electric car settings allowed understanding the validity of the car brand Tesla Model S90D for the use on the highways and at relatively small environmental temperatures. This provided an opportunity to form the range of parameters and settings that are necessary to use the car in conditions of highway and low temperature.

2. It is established that electric car accumulator battery significantly reduces its capacity at negative temperatures; the capacity lowers by $1 \%$ per every degree of frost - i.e. at $-10{ }^{\circ} \mathrm{C}$ the capacity of electric car accumulator battery and distance traveled on one charge will reduce by $10 \%$, which causes the increase of charging frequency in winter. Based on the road testing, the comfortable temperature is set for the usage of electric car accumulator battery in the range from 0 to $20{ }^{\circ} \mathrm{C}$ moreover, the temperature growth also causes the reduction of the capacity because of intensive battery cooling - system protects it from overheating.

3. By the results of the conducted research, it is established that the usage of the energy-saving regime of electric car battery allows reducing the energy consumption. For the speed of 65 $\mathrm{km} / \mathrm{h}$ and with turned on energy consumers the reduction of energy consumption is by $29 \%$, and with turned off energy consumers - by $14 \%$. At the speed of $95 \mathrm{~km} / \mathrm{h}$ and with turned on energy consumers the reduction of energy consumption is by $16 \%$, and with turned off energy consumers - by $22 \%$.

4. The impact of tire pressure values is essential on the level of electric car battery charge, and lowered pressure in tires for $65 \mathrm{~km} / \mathrm{h}$ increases energy consumption regardless of turning on the energy consumers to $10 \%$, and at speed $95 \mathrm{~km} / \mathrm{h}$ and with turned off energy consumers the reduction is $30 \%$ but with turned on energy consumers $-40 \%$.

\section{References}

1. Kachmar, R., \& Lanets, O. (2020). The impact of parameters of traffic flows of Lviv street-road network on the level of environmental and economic losses. Transport Technologies, Volume 1, Issue 1, 83-91. doi: 10.23939/tt2020.01.083 (in English)

2. Zakhid Epokhy DVZ De I Koly Povnistiu Zaboroniat Avtomobili Z Dyzelnymy I Benzynovymy Dvyhunamy [West of the ICE: Where and when will completely ban cars with diesel and gasoline engines]. Retrieved from: https://fra.org.ua/uk/an/publikatsii/novosti/zakhid-iepokhi-dvz-die-i-koli-povnistiu-zaboroniat-avtomobili-z-dizielnimi-i-bienzinovimi-dvighunami (in Ukrainian)

3. Staufenberg, J. (2016). Norway to 'completely ban petrol powered cars by 2025 '. The Independent, 4. (in English)

4. Here's How Electric Cars Will Cause the Next Oil Crisis Retrieved from: https://www.bloomberg.com/features/2016-ev-oil-crisis/ (in English)

5. Model S Survey Data Overview Retrieved from: https://survey.pluginamerica.org/model-s/charts.php. (in English)

6. Rynok elektromobiliv v ukraini stanovlennia ta perspektyvy [Electric car market in Ukraine: formation and prospects]. Retrieved from: http://nbuviap.gov.ua/index.php?option=com_content\&view=article\&id=3013:rinok elektromobiliv-v-ukrajini-stanovlennya-ta-perspektivi\&catid $=8 \&$ Itemid $=350$ (in Ukrainian)

7. Federatsiia Robotodavtsiv Avtomobilnoi Haluzi [Federation of Automotive Employers]. Retrieved from: https://fra.org.ua/uk/st/statistika/infoghrafika/park-elektromobiliv-v-ukrayini (in Ukrainian)

8. Yaki problemy elektrokariv pryiniato zamovchuvaty [What problems of electric cars it is accepted to be silent]. Retrieved from: https://www.autocentre.ua/ua/news/shest-problem-elektrokarov-o-kotoryh-ne-prinyatogovorit-1169260.html (in Ukrainian)

9. Yarovyi Ye. V. \& Kravtsov M. M. (2020). Kompyuterna diahnostyka nespravnosti elektromobilya [Computer diagnostics of electric vehicle malfunction]. Kompiuterni Tekhnolohii I Mekhatronika [Computer technology and mechatronics] (pp. 171-15). - Kharkiv (in Ukrainian) 
10. Ohliad Avtomobilnoi Promyslovosti No. 79 [Review Automotive industry Nj 79]. Retrieved from: https://fra.org.ua/uploads/media/file/0001/07/7dc72400a3e5a1a155226bc7c9ee46220e45b32b.pdf (in Ukrainian)

11. Voitkiv S. V. (2020). Tendentsii i perspektyvy rozvytku elektromobiliv maloi vantazhopidiomnosti. [Trends and prospects for the development of light-duty electric vehicles]. Avtomobil i elektronika. suchasni tekhnolohii [Vehicle and electronics. Innovative technologies], (18), 17-17. doi: 10.30977/VEIT.22269266.2020.18.0.17 (in Ukrainian)

12. Batarei na kolesakh [Batteries on wheels]. Retrieved from: https://fra.org.ua/uploads/media/default/0001/07/3e8332e0ed57859c6bfa1dc8e3e1b0e7e194427a.pdf (in Ukrainian)

13. Vidomenko O. I. (2017). Perspektyvy rozvytku elektromobilnoho transportu v Ukraini [Prospects for the development of electric vehicles in Ukraine]. Naukova Dumka: Materialy Mizhnarodnoi Naukovo-Praktychnoi Konferentsii [Scientific opinion: Materials of the International scientific-practical conference,] (pp. 50-54). - Odessa (in Ukrainian) English)

14. The World's Fastest Charging Station. Retrieved from: https://www.Tesla.com/en_EU/supercharger. (in

15. Andrusenko S. I. Buhaichuk O. S. Loboda A. V. \& Savostin-Kosiak D. O. (2020). Otsinka vartostei ekspluatatsii transportnykh zasobiv z riznymy typamy sylovykh ustanovok [Evaluation of operating costs of vehicles with various types of power plants]. Zhurnal Tekhnichna Inzheneriia [The Journal "Technical Engineering”], 2 (86), 3-12. (in Ukrainian)

16. Gavrilyk A. F. \& Lemishko M. V. (2019). Analiz ekvivalentnoi palyvnoi oshchadlyvosti elektromobiliv [Analysis of equivalent fuel savings of electric vehicles]. Visnyk LDUBZhD [Bulletin of Lviv State University of Life Safety], 20, 85-89. (in Ukrainian)

17. Logtenberg, R., Pawley, J., \& Saxifrage, B. (2018). Comparing fuel and maintenance costs of electric and gas powered vehicles in Canada. 2 Degrees Institute. (in English)

18. Smyrnov O. P. Bohaievskyi O. B., \& Pihariev R. I. (2013). Problemy ta perspektyvy rozvytku elektromobiliv [Problems and prospects of electric vehicles]. Avtomobil i elektronika. suchasni tekhnolohii [Vehicle and electronics. Innovative technologies], 4, 19-23. (in Ukrainian)

19. Smyrnov O. P. Borysenko A. O. \& Marchenko A. V. (2020) Doslidzhennia elektropryvodu TESLA Model S. [Research of the TESLA model S electric drive.] Retrieved from: https://dspace.khadi.kharkov.ua/dspace/bitstream/123456789/3577/1/247-249.pdf.

Received 09.03.2021; Accepted in revised form 08.04.2021.

\title{
ОСОБЛИВОСТІ ЕКСПЛУАТАЦІї ЕЛЕКТРИЧНОГО АВТОМОБІЛЯ TESLA MODEL S90D В УМOBAX MICT УКРАЇНИ
}

\begin{abstract}
Анотація. Тенденції сталого розвитку транспорту, використання альтернативних джерел енергії та вимоги зменшення вуглечевого сліду на всіх етапах життєвого ииклу $і$ на усіх рівнях автомобільної техніки привели до збільшення частки електромобілів, як із первинною реєстрацією, так і вжсиваних транспортних засобів. Поява на ринку великої кількості вживаних сучасних електромобілів зумовила потребу розроблення процедур забезпечення їх технічної експлуатачії як відповідно до вимог рачіонального користування, так і для забезпечення безпеки руху. Виконано дослідження щодо використання електромобіля Tesla Model S90D в умовах Украӥни за певних показників навколишнього середовища та за різних налаштувань параметрів електромобіля. Це дало змогу зрозуміти, наскільки ия модель електромобіля придатна для експлуатачї в тих чи інших умовах, а також визначити, які параметри налаштування електромобіля найбільше підходять для економного використання у різних умовах та в різні пори року. Дослідженнями зміни ємності
\end{abstract}


акумуляторної батареї електромобіля залежно від температури довкілля встановлено, щьо ємність зменшується на 1 \% на кожен градус від'ємної температури. Визначено комфортний діапазон температур для використання акумуляторної батареї електромобіля $\left(0-20{ }^{\circ} \mathrm{C}\right)$. Визначено також показники ефективності застосування режиму енергозбереження батареї електромобіля - зменшення споживання досягає 14-29\% залежно від увімкнених споживачів енергії. Встановлено істотний вплив тиску в шинах електромобіля на споживання енергії незалежно від ввімкнення споживачів енергії - збільшення від $10 \%$ до $40 \%$ залежно від його швидкості руху. Додатково визначено показники енергоефективності електромобіля для швидкості 140-150 км/год, за якого споживання енергії становить 550-670 Вт-год/км і забезпечує запас ходу на рівні $160 \mathrm{kм.}$

Ключові слова: електромобіль, експлуатація, технічне обслуговування, несправності, дефекти, енергоспоживання, акумуляторна батарея, рекуперація, енергоспоживання. 